\title{
Factors affecting the milk yield, milk composition and physico-chemical parameters of ghee in lactating crossbred cows
}

\author{
N Veena $^{1}$, JS Hundal $^{2}$, M Wadhwa $^{2}$ and AK Puniya ${ }^{3}$
}

Received: 08 April 2020 / Accepted: 07 November 2020 / Published online: 28 February 2021

(C) Indian Dairy Association (India) 2021

\begin{abstract}
The aim of this study was to investigate the effect of season, production status, stage of lactation, and parity on milk yield, milk composition and physico-chemical parameters of ghee in forty crossbred cows (CBCs). Milk samples were collected from individual animal during morning in both summer (MayAugust) and winter (November-February) season. The results revealed that milk yield was significantly influenced by the production status and lactation stage. The fat percentage was significantly affected by the stage of lactation and parity. However, protein percentage was affected by the season and stage of lactation. An effect of season, stage of lactation and parity on butyro-refractometer (BR) reading of ghee was significant. The Reichert-meissl (RM) value of CBCs ghee was significantly influenced by the parity whereas Polenske value by the production status and parity. Results also indicated that the $\mathrm{RM}$ value of $\mathrm{CBCs}$ ghee was found to be below the legal standard of minimum 28 in Punjab state.
\end{abstract}

Keywords: Crossbred cows, Milk yield, Milk composition, Physico-chemical parameters of ghee

\section{Introduction}

Development of breeding programs for changing the composition of milk requires knowledge of the relative influence of genetic

\footnotetext{
${ }^{1}$ Department of Dairy Chemistry, College of Dairy Science and Technology; Guru Angad Dev Veterinary and Animal Sciences University, Ludhiana, 141 004, Punjab, India

${ }^{2}$ Department of Animal Nutrition, College of Veterinary Science, Guru Angad Dev Veterinary and Animal Sciences University, Ludhiana, 141 004, Punjab, India

${ }^{3}$ Dairy Microbiology Division, ICAR-National Dairy Research Institute, Karnal, 132 001, Haryana, India

N Veena ${ }^{1 *}(\square)$

Department of Dairy Chemistry, College of Dairy Science and Technology; Guru Angad Dev Veterinary and Animal Sciences University, Ludhiana, 141 004, Punjab, India

Email: veena.ndri@gmail.com
}

(stage of lactation, pregnancy, breed, parity etc) and non-genetic (nutrition, season of calving, temperature etc) factors affecting milk constituents (Sudhakar et al. 2013). Augmenting lactation milk yield has been emphasized for increasing the productivity of dairy animals; however, milk constituents such as fat, protein and lactose percentages have so far received little attention in breeding programs.

The physico-chemical quality of ghee (clarified butterfat) is usually assessed by analyzing certain characteristics such as Reichert-Meissl (RM) value, Polenske value (PV), Butyrorefractometer (BR) reading, Iodine value and Saponification value. These analytical characteristics are mostly the reflections of the fatty acid composition of the milk lipid (Veena et al. 2020) and vary with region to region and season to season, depending on the type of breed and the feed. For instance, RM value is substantially a measure of the lower chain volatile water soluble fatty acids i.e butyric acid $\left(\mathrm{C}_{4: 0}\right)$ and caproic acid $\left(\mathrm{C}_{6: 0}\right)$ whereas Polenske value is a measure of lower chain volatile water insoluble fatty acids i.e caprylic acid $\left(\mathrm{C}_{8: 0}\right)$ and capric acid $\left(\mathrm{C}_{10: 0}\right)$. Butyrorefractometer $(\mathrm{BR})$ reading, which measures the index of refraction between air and the liquid fat and varies with the nature of the fat, is usually determined at $40^{\circ} \mathrm{C}$ (Veena et al. 2018; Veena et al. 2020). However, the composition of milk as well as fatty acid composition is largely affected by various factors i.e., lactation stage, lactation number, breed, season and environmental factors. The available information on various factors influencing the composition of milk and physicochemical properties of milk fat/ ghee is scanty in crossbred cows. Moreover Punjab state is endowed with highly productive population of crossbred cattle, closer to the Holstein Friesian both in production traits and in appearance. Thus the present investigation was undertaken with the objective to study the effect of various factors affecting the milk yield, milk composition and chemical parameters of ghee, prepared from milk of crossbred cows.

\section{Materials and Methods}

\section{Sample collection and analysis}

Forty crossbred cows from the Livestock farm of Guru Angad Dev Veterinary and Animal Sciences University (GADVASU, 
Ludhiana, Punjab, India) were kept under farm management. Diet of crossbred cows was met through green fodder ( $a d$ lib.) and concentrate according to milk production. All the experimental animals were offered identical ration to meet production/ maintenance requirement to negate the feeding effect on milk production. The animals had free access to water throughout the day. Feed samples offered in two different seasons (May-August and November - February) were collected and ground to pass through $1 \mathrm{~mm}$ sieve and then analyzed for fat, protein, acid detergent fibre (ADF) and neutral detergent fibre (NDF) content (Robertson and Van Soest, 1981).

The crossbred cows were grouped according to production status (high yielders, >15 kg/day; medium yielders, $8-15 \mathrm{~kg} /$ day; low yielders, $<8 \mathrm{~kg} /$ day), stage of lactation (early - up to 100 days of postpartum; mid - 101 to 200 days; late - more than 201 days of postpartum) and parity ( $1^{\text {st }}$ to $4^{\text {th }}$ lactation). Milk samples were collected from individual animal during morning in both summer (May - August) and winter (November - February) season. Milk yield was recorded after complete milking. Contents of fat, solidnot-fat (SNF) and protein in milk samples were analyzed by a MilkoScreen (Indifoss Analytical Pvt Ltd, Ahmedabad, India). Cream was separated from each of the individual milk samples by centrifugal method in the cream separator. Cream samples were then converted to ghee by direct cream method as described by De (2005). Ghee samples were stored in refrigerator $\left(4^{\circ} \mathrm{C}\right)$ till for further analysis. Ghee samples were analyzed for RM and PV as per the standard procedure described in IS: 3508 (ISI, 1966). Butyro refractometer (BR) reading of ghee was measured using digital butyro refractometer (Atago Co Ltd, Tokyo, Japan).

\section{Statistical analysis}

Milk samples were collected twice in each season from 40 animals. Mean values and pooled standard error of duplicate determinations were reported. Statistical significance was set at $\mathrm{P}<0.05$. The data was analyzed in a factorial design (Snedecor and Cochran, 1994) by using the software package SPSS version 16 (SPSS 1996) and differences in mean were assessed by using Tukey's b test.

Table 1. Composition of the feed offered to CBCs in different seasons

\begin{tabular}{llc}
\hline Parameter & Season & \\
\cline { 2 - 3 } & Summer & Winter \\
\hline Dry matter, kg /day & 16.3 & 14.9 \\
Roughage : Concentrate ratio & $55: 45$ & $49: 51$ \\
Crude Protein, \% & 15.5 & 20.1 \\
Fat, \% & 2.97 & 3.59 \\
NDF, \% & 52.42 & 37.8 \\
ADF, \% & 32.39 & 22.7 \\
\hline
\end{tabular}

Results are expressed as mean values, $n=5$

\section{Results and Discussion}

The chemical composition of feed offered to crossbred cows in different season is shown in the Table 1.The animals were offered green fodder and concentrate in the ratio of 55 to 45 and 49 to 51, respectively in the summer and winter season. The total dry matter intake was 16.3 and $14.9 \mathrm{~kg} / \mathrm{d}$, respectively in the summer and winter season. The crude protein and fat content were higher in the winter fodder, whereas NDF and ADF content were higher in the summer fodder.

\section{Effect of season on milk yield, milk composition and physico- chemical parameters of ghee}

The seasonal differences can attributed to the differences in quality and quantity of available fodder and climatological variation in different seasons which have direct impact on production traits. The data in Table 2 revealed that milk yield and fat content of lactating CBCs was not affected by the season. Many workers (Nehra 2011, Radhika et al. 2012) reported no significant effect of season and period of calving on the first lactation milk yield. Radhika et al. (2012) reported that season of calving had no significant effect on milk fat percentage. However, the protein and SNF content were significantly lower $(\mathrm{P}<0.05)$ in winter than summer season. According to Sarkar et al. (2006) milk composition traits were highest in hot humid season but lowest in milk yield as compared to other seasons. The daily yield of fat and protein was observed to be higher during summer $(\mathrm{P}<0.05)$ than winter season.

The RM and PV of ghee were found to be slightly higher in summer than that found in the winter, however, significant difference were not observed (Table 2). The RM value of ghee was found to be 25.04 in winter and 25.79 in summer, while PV was 1.08 and 1.12 , respectively. The previous findings were expected because the summer milk fat contained higher levels of $\mathrm{C}_{4}$ and $\mathrm{C}_{6}$ acids than the one found in the winter milk fat (Laurelle et al. 1976). However, this discrepancy between both fats and in their fatty acid levels was due to the effect of the season of the year and consequently the plane of nutrition (McDowall and McGillivary, 1963; Hall, 1970; Gray, 1973). The BR reading was found to be lower $(\mathrm{P}<0.05)$ in summer compared to winter season.

\section{Effect of production status on milk yield, milk composition and physico-chemical parameters of ghee}

Effect of production status on milk yield, milk composition and physico-chemical parameters of ghee is represented in the Table 3 . The milk yield varied from $5.58 \mathrm{~kg} / \mathrm{d}$ (low yielders) to $19.71 \mathrm{~kg} /$ $\mathrm{d}$ (high yielders) and significantly affected $(\mathrm{P}<0.05)$ by the production status. The fat content varied $(\mathrm{p}>0.05)$ from 3.63 (medium yielders) to 4.21 per cent (high yielders). The production status of animals showed no significant effect on fat, protein and SNF content. The daily fat and protein yield was affected 
$(\mathrm{p}<0.05)$ by the production status of the animals and was observed to be higher in high yielding dairy animals as compared to low yielding animals and this is due to differences in daily milk yield.

The data on physiochemical parameters revealed that RM value was not affected by production status of the CBCs. The production status of animals influenced $(p<0.05)$ the PV and it was observed to be low in low yielders $(0.94)$ and high in high yielders (1.2). The BR value was not affected by the production status of animals and was within the normal range of 41-43.

\section{Effect of stage of lactation on milk yield, milk composition and physiochemical parameters CBCs}

The daily milk yield was observed to vary from 11.4 (mid lactation) to $14.5 \mathrm{~kg}$ (early lactation) (Table 4). The fat content of CBCs increased linearly with the advancement of lactation and values were higher $(p<0.05)$ during late than mid and early lactation. The increase in total lipid contents may be due to the activity of fatty acid synthesizing enzymes particularly acetyl CoA carboxylase which is a regulatory enzyme in the fatty acid synthesis might have slightly increased in late lactation than early and mid lactation (Sharma et al. 2000). The daily fat yield was observed to be higher $(p<0.05)$ from animals in late lactation in comparison to animals in early stage of lactation and correlates well with milk yield and fat content during different stages of lactation. Similarly protein content was also increased with progress of lactation stage. No influence of stage of lactation was observed on SNF content and protein yields. Bhoite and Padekar (2002) reported a non significant effect of stage of lactation for fat in Holstein crosses but a significant effect in crosses involving Jersey. Sarkar et al., (2006) reported that lactation stage had no influence on fat content but a significant effect on protein, SNF and lactose content.

The data on physicochemical properties of milk fat (Table 4) revealed that RM and PV were slightly higher in early and late lactation period compared to mid lactation, however, significant differences were not observed. Studies reported that proportions

Table 2. Effect of season on milk yield, milk composition and physico-chemical parameters of ghee

\begin{tabular}{lllc}
\hline Parameter & \multicolumn{1}{c}{ Season $^{\#}$} & PSE \\
\cline { 2 - 4 } & Summer & Winter & 0.50 \\
Milk yield kg/day & 12.17 & 13.20 & 0.19 \\
Fat, \% & 4.00 & 3.78 & 0.070 \\
Protein, \% & $4.03^{\mathrm{b}}$ & $3.45^{\mathrm{a}}$ & 0.15 \\
SNF, \% & $9.85^{\mathrm{b}}$ & $9.22^{\mathrm{a}}$ & 0.036 \\
Fat, kg/day & $0.56^{\mathrm{b}}$ & $0.36^{\mathrm{a}}$ & 0.032 \\
Protein, kg/day & $0.52^{\mathrm{b}}$ & $0.35^{\mathrm{a}}$ & 0.30 \\
RM value & 25.79 & 25.04 & 0.05 \\
Polenske value & 1.12 & 1.08 & 0.12 \\
BR reading & $41.59^{\mathrm{a}}$ & $42.88^{\mathrm{b}}$ & \\
\hline
\end{tabular}

Mean values with different superscripts in a row differ significantly $(\mathrm{P}<0.05)$.

"Irrespective of lactation number, stage of lactation and production status. PSE-Poolesd standard error

Table 3. Effect of production status on milk yield, milk composition and physico-chemical parameters of ghee

\begin{tabular}{|c|c|c|c|c|}
\hline \multirow[t]{2}{*}{ Parameter } & \multicolumn{2}{|r|}{ Production } & \multicolumn{2}{|l|}{ status $^{\#}$} \\
\hline & High & Medium & Low & PSE \\
\hline $\begin{array}{l}\text { Milk yield } \\
\text {, kg/day }\end{array}$ & $19.71^{\mathrm{c}}$ & $12.76^{b}$ & $5.58^{a}$ & 0.61 \\
\hline Fat, $\%$ & 3.83 & 3.63 & 4.21 & 0.22 \\
\hline Protein, \% & 3.70 & 3.69 & 3.84 & 0.08 \\
\hline SNF, \% & 9.46 & 9.53 & 9.62 & 0.18 \\
\hline RM value & 25.44 & 25.76 & 25.04 & 0.36 \\
\hline Polenske value & $1.20^{\mathrm{b}}$ & $1.18^{\mathrm{b}}$ & $0.94^{\mathrm{a}}$ & 0.058 \\
\hline $\mathrm{BR}$ reading & 42.23 & 42.09 & 42.38 & 0.11 \\
\hline
\end{tabular}

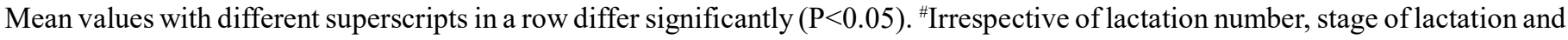
season. PSE-Poolesd standard error 
of short- and medium-chain fatty acids $\left(\mathrm{C}_{6: 0}\right.$ to $\left.\mathrm{C}_{14: 0}\right)$ increased during the first 3 months of lactation and decreased after that, whereas long chain fatty acids followed opposite trend (Mele et al. 2009; Stoop et al. 2009). Butyric acid showed a decreasing trend as lactation progressed for all parities while the proportion of $\mathrm{C}_{6: 0}$ to $\mathrm{C}_{14: 0}$ fatty acids were lower at the beginning of the lactation, increased first 100 days of lactation and remained steady for the rest of the lactation period (Bilal et al. 2014). The BR reading varied $(\mathrm{p}<0.05)$ in a narrow range of 41.9 (late) to 42.5 (mid) and increased up to mid stage of lactation and decreased thereafter.

\section{Effect of parity on milk yield, milk composition and physio- chemical parameters of ghee}

Effect of parity on milk yield, milk composition and physicochemical parameters of ghee in CBCs is represented in the Table 5. With increase in parity the milk yield increased linearly but the differences were not significant. The milk fat was observed to be highest $(\mathrm{p}<0.01)$ in primiparous cows in comparison to multiparous cows (Table 5). A decrease in milk fat percentage of
$0.2 \%$ over five lactations has been reported by Rogers and Stewart (1982). However, the protein and SNF content were not affected by the parity. Contrary to the present findings Suman (2009a) and Suman (2009b) observed significant effect of parity on SNF and protein content, respectively. Radhika et al., (2012) and Sarkar et al (2006) reported milk yield and milk composition traits were not differed significantly in different parities. The fat and protein yield was observed to be highest $(\mathrm{p}<0.01)$ in multiparous animals (4th lactation). Wathes et al. (2007) suggested that there are differences between primiparous and multiparous cows in the control of tissue mobilization that may promote nutrient partitioning into growth, as well as milk during the first lactation.

Both RM and PV were significantly influenced $(\mathrm{P}<0.05)$ by the parity but no systematic trend could be observed. The RM value varied from 24.7 ( $2^{\text {nd }}$ lactation) to 26.6 ( $4^{\text {th }}$ lactation). The PV was observed to be highest of ghee obtained from animals in $4^{\text {th }}$ parity and lowest in $3^{\text {rd }}$ parity. The BR reading varied in a very narrow range of 42.04 (1st) to 42.59 (2nd lactation). The BR reading was observed to be lower in the first parity and differ significantly from other lactation numbers.

Table 4. Effect of stage of lactationon milk yield, milk composition and physico-chemical parameters of ghee

\begin{tabular}{llllc}
\hline Parameter & \multicolumn{3}{c}{ Stage of lactation ${ }^{\#}$} \\
\cline { 2 - 4 } & Early lactation & Mid lactation & Late lactation & PSE \\
\hline Milk yield, kg/day & $14.45^{\mathrm{b}}$ & $11.42^{\mathrm{a}}$ & $12.17^{\mathrm{a}}$ & 0.58 \\
Fat, \% & $3.42^{\mathrm{a}}$ & $4.04^{\mathrm{b}}$ & $4.22^{\mathrm{c}}$ & 0.21 \\
Protein, \% & $3.58^{\mathrm{a}}$ & $3.72^{\mathrm{a}}$ & $3.92^{\mathrm{b}}$ & 0.079 \\
SNF, \% & 9.30 & 9.42 & 9.89 & 0.17 \\
Fat, kg/day & $0.38^{\mathrm{a}}$ & $0.43^{\mathrm{ab}}$ & $0.56^{\mathrm{c}}$ & 0.041 \\
Protein, kg/day & 0.42 & 0.37 & 0.44 & 0.037 \\
RM value & 25.88 & 24.79 & 25.57 & 0.35 \\
Polenske value & 1.08 & 1.06 & 1.17 & 0.055 \\
BR reading & $42.23^{\mathrm{b}}$ & $42.51^{\mathrm{b}}$ & $41.97^{\mathrm{a}}$ & 0.11
\end{tabular}

Mean values with different superscripts in a row differ significantly $(\mathrm{P}<0.05)$. ${ }^{\#}$ Irrespective of lactation number, production status and season. PSE-Poolesd standard error

Table 5. Effect of parity on milk yield, milk composition and physico-chemical parameters of ghee

\begin{tabular}{llllll}
\hline Parameter & \multicolumn{3}{l}{ Parity $^{\#}$} & $4^{\text {th }}$ & \\
\cline { 2 - 5 } & $1^{\text {st }}$ & $2^{\text {nd }}$ & $3^{\text {rd }}$ & 13.95 & $0.5 S E$ \\
Milk yield kg/day & 12.0 & 12.32 & 12.47 & $3.52^{\mathrm{a}}$ & 0.24 \\
Fat, \% & $4.50^{\mathrm{b}}$ & $3.54^{\mathrm{a}}$ & $3.99^{\mathrm{a}}$ & 3.95 & 0.09 \\
Protein, \% & 3.44 & 3.81 & 3.76 & 9.85 & 0.20 \\
SNF, \% & 9.0 & 9.69 & 0.61 & $0.60^{\mathrm{b}}$ & 0.046 \\
Fat, kg/day & $0.37^{\mathrm{b}}$ & $0.34^{\mathrm{a}}$ & $0.44^{\mathrm{a}}$ & $0.63^{\mathrm{b}}$ & 0.041 \\
Protein, kg/day & $0.28^{\mathrm{a}}$ & $0.36^{\mathrm{a}}$ & $25.20^{\mathrm{a}}$ & $26.61^{\mathrm{b}}$ & 0.40 \\
RM value & $25.15^{\mathrm{ab}}$ & $24.70^{\mathrm{a}}$ & $0.99^{\mathrm{a}}$ & $1.25^{\mathrm{b}}$ & 0.062 \\
Polenske value & $1.13^{\mathrm{b}}$ & $1.04^{\mathrm{ab}}$ & $42.22^{\mathrm{b}}$ & $42.09^{\mathrm{b}}$ & 0.16
\end{tabular}

Mean values with different superscripts in a row differ significantly $(\mathrm{P}<0.05) .{ }^{\#}$ Irrespective of season, stage of lactation and production status. PSE-Poolesd standard error 


\section{Incidence of low RM value}

The RM value of ghee prepared from crossbred cow's milk was found to be below the FSSAI standard of minimum 28 in Punjab state (FSSA, 2006), irrespective of season, stage of lactation, production status and parity. This may be attributed to the fact that crossbred cows of Punjab has more of Holstein Friesian inheritance and hence produce milk of low fat percentage with low RM value compared to indigenous breeds of cow. There are numerous references in the literature about the effect of various rations on the RM value of butterfat (Arup, 1929; Geisler, 1926, Hawley, 1933; Overman and Garrett, 1932; Sutton et al., 1932). In some instances extremely low RM numbers have been obtained (Arup, 1929; Hawley, 1933; Sutton et al., 1932). These were invariably caused by extreme or unusual feeding conditions. Stout and Wilster (1939) reported that the lowest RM value was produced in a region where alfalfa hay formed the major portion of the ration. It is recognized that feed influences butterfat composition and inherent glyceride composition. Kehar et al. (1956) who studied the effect of breed, season and locality on some of chemical constants of ghee prepared from milk collected from 12 farms in different parts of India. They observed that RM and Polenske values for ghee samples lay between 16 and 34.76 (average 24.29) and 1.1 and 2.8 (average 1.77), respectively. More studies needs to be conducted before a definite conclusion is drawn about the incidence of low RM value in the milk fat of CBCs in Punjab state.

\section{Conclusions}

From study, it was observed that effect of season, lactation stage, production status and parity were visible in milk yield, milk composition and chemical parameters of $\mathrm{CBCs}$ ghee. Average milk yield was significantly influenced by stage of lactation and production status. An effect of season, stage of lactation and parity on butyro-refractometer (BR) reading of ghee was significant. The fat percentage was significantly affected by the stage of lactation and parity. However, protein percentage was affected by the season and stage of lactation. The RM value of CBCs ghee was significantly influenced by the parity whereas PV by the production status and parity. Results of this study also revealed that RM value of CBCs ghee was appears to be below the FSSAI standard of minimum 28 in Punjab state. It is, therefore, necessary that much more detailed work should be undertaken on the effect of climate, feed, breed/species and method of management on the chemical parameters of ghee to ascertain the proper ranges for Indian standards.

\section{Acknowledgement}

Authors are thankful to the Punjab State Cooperative Milk Producer's Federation Limited, Chandigarh for providing financial assistance for carrying out this research work.

\section{References}

Arup PS (1929) The Composition of Irish winter butter. Analyst 54: 634645

Bhoite UY, Padekar RN (2002) Factors affecting milk yield and composition. Indian J Animal Res 36: 67-69

Bilal G, Cue RI, Mustafa AF, Hayes JF (2014) Effects of parity, age at calving and stage of lactation on fatty acid composition of milk in Canadian Holsteins. Can J Anim Sci 94: 401-410

De S (2005) Outlines of Dairy Technology. Oxford Publishing Company, New Delhi

FSSA (2006) The Food Safety and Standards Act. Universal's, New Delhi, India

Geisler JG (1926) The Effect of Cottonseed Feeding on Butterfat. J Oil Fat Inds 3: 115-118

Gray IK (1973) Seasonal variations in the composition and thermal properties of New Zealand milk fat, I. Fatty acid composition. J Dairy Res 40: 207-214

Hall AJ (1970) Seasonal and regional variations in the fatty acid composition of milkfat. Dairy Industries 35: 20-24

Hawley H (1933) The Phytosterol acetate test as a routine method in the examination of butterfats with borderline Reichert-Meissl values. Analyst 58: 529-531

ISI (1966) Methods of Sampling and Test for Ghee (Butter Fat) (3508: 1966). Bureau of Indian Standards, Manak Bhavan, New Delhi

Kehar ND, Ray SN, Joshi BC, Raisarkar BC (1956) Chemical constants of pure ghee. In: Studies on Fats, Oils and Vanaspatis. Manager of Publications, Delhi, p. 5-12

Laurelle L, Van DM, Daenens P (1976) Fatty acid composition of Reichertmeissl and Polenske fractions in butterfat. J Dairy Res 43: 137-140

McDowall FH, McGillivary WA (1963) Studies on the properties of New Zealand butterfat, VI. Comparision of the properties and vitamin A potencies of butterfats produced by clover-fed and ryegrass-fed dairy cows. J Dairy Res 30: 47-57

Mele M, Dal Zotto R, Cassandro M, Conte G, Serra A, Buccioni A, Bittante G, Secchiari P (2009) Genetic parameters for conjugated linoleic acid, selected milk fatty acids, and milk fatty acid unsaturation of Italian Holstein-Friesian cows. J Dairy Sci 92: 392-400.

Nehra M (2011) Genetic analysis of performance trends in Karan- Fries cattle. M.Sc. Thesis, ICAR-National Dairy Research Institute (Deemed University), Karnal, India

Overman OR, Garrett OF. (1932) The Influence of certain balanced rations on the chemical and physical properties of milk fat. J Agric Res 45: 51-58

Radhika G, Ajithkumar S, Rani A, Sathian CT, Anilkumar K, Usha AP, Dinesh CN (2012) Milk yield and composition of crossbred cows in the hilly Wayanad district of Kerala, India. Indian J Animal Sci 82: 1251-1254

Robertson JA, Van Soest PJ (1981) The detergent system of analysis and its application on human food. In: James W.P.T. and O. Theander (eds), The Analysis of Dietary Fibre in Food, Marcel Dekkar Inc., New York, pp 123-158

Rogers GL, Stewart JA (1982) The effects of some nutritional and nonnutritional factors on milk protein concentration and yield. Aust J Dairy Technol 37: 26-32

Sarkar U, Gupta AK, Sarkar V, Mohanty TK, Raina VS, Prasad S (2006) Factors affecting test day milk yield and milk composition in dairy animals. J Dairying Foods HS 25: 129-132

Sharma KC, Sachdeva VK, Singh S (2000) A comparative gross and lipid composition of Murrah breed of buffalo and cross-bred cow's milk during different lactation stages. Arch Tierz Dummerstorf 43: 123130 
Snedecor GW, Cochram WG (1994) Statistical Methods. Oxford and IBH Publications, New Delhi

SPSS (1996) Statistical packages for social sciences. Version 12.0, SPSS Inc., Linois, USA

Stoop WM, Bovenhuis H, Heck JML, van Arendonk JAM (2009) Effect of lactation stage and energy status on milk fat composition of Holstein-Friesian cows. J Dairy Sci 92: 1469-1478.

Stout RE, Wilster GH. (1939) Some observations on the Iodine, ReichertMeissl and Polenske values of milk fat produced during the winter in three sections of Oregon. J Dairy Sci 22: 424-425

Sudhakar K, Panneerselvam S, Thiruvenkadan A K, Abraham J, Vinodkumar G (2013) Factors effecting milk composition of crossbred dairy cattle in Southern India. Int J Food Agric Vet Sci 3: 229-233

Suman CL (2009a) Lactation trend of milk solid-not-fat in two-breed crosses of cattle at an organized farm. Indian J Animal Res 43: 1216

Suman CL (2009b) Algebric functions describing lactation trend of milk Protein in two-breed crosses of cattle. Indian J Animal Res 43: 6266
Sutton TS, Blcown JB, Johnston EW (1932) The Effect of corn oil on milk and butterfat production and on the composition of butterfat in the dairy cow. J Dairy Sci 15: 209-211

Veena N, Wadhwa M, Hundal JS, Puniya AK (2020) Factors affecting milk yield, milk composition and physic-chemical parameters of ghee in Murrah buffaloes of Punjab region. Indian J Dairy Sci 73: 40-45

Veena N, Wadhwa M, Mehta H, Barui AK, Puniya AK, Hundal JS, Grewal RS (2018) Effect of supplementing bypass fat on milk yield, milk composition and chemical parameters of ghee in crossbred Cows. Int J Curr Microbiol App Sci 7: 2604-2609

Wathes DC, Cheng Z, Bourne N, Taylor VJ, Coffey MP, Brotherstone S (2007) Differences between primiparous and multiparous dairy cows in the inter-relationships between metabolic traits, milk yield and body condition score in the periparturient period. Domest Anim Endocrinol 33: 203-225 